\title{
Investigation of Locus Beans Waste Ash as Partial Replacement for
}

\section{Cement in Concrete Structures}

\author{
${ }^{1}$ Hadiza Ali, ${ }^{2}$ Rintong Isaac Babatunde, ${ }^{3}$ Abdulrauf Ibrahim and ${ }^{4}$ Adejoh B.O \\ ${ }^{1,2,4}$ Department of Civil Engineering, Kaduna Polytechnic \\ ${ }^{3}$ Department of Mechanical Engineering, Kaduna Polytechnic
}

Nigeria

\begin{abstract}
This study is aimed at investigating the compressive strength of concrete using locust beans waste ash (LBWA) as a replacement for cement in concrete using three grades of concrete; grade 20, 25 and 30 respectively, the concrete cube cast was; control (0\%) $5 \%, 10 \%$ and $15 \%$ respectively. the cube was cast, cured and tested at 7 days, 14 days. 21 days and 28 days. Although, the results of this study have shown a significant reduction in compressive strength of concrete utilizing LBWA than normal concrete, it could be recommended that LBWA concrete should be used in road kerbs, concrete blocks, non-bearing concrete walls, precast units (partition walls, concrete blocks for Architectural applications and some cases of slabs on soil, culverts, sidewalks, drive ways), foundation pads for machinery.
\end{abstract}

Keywords: Cementious material, Compressive strength, Concrete, locust beans waste ash, Pozzolana.

\subsection{INTRODUCTION}

Locust bean pod husks are a waste by-products of agricultural processing of the African locust bean fruit. Substantial quantities can be found across northern Nigeria during the harvest season. Across the globe, much research efforts in recent times are geared towards possible ways of recycling these wastes for reuse to keep the environment clean and safe (Adama \& Jimoh, 2011). The transportation, construction, and environmental industries have the greatest potential for reuse because they use large quantities of earthen materials annually (Basha, 2003).

Locust bean pod, which is a Waste Agricultural Biomass (WAB) obtained from the fruit of the African locust bean tree (ParkiaBiglobosa), is the material resource required for the production of locust bean pod ash (LBPA). The harvested fruits are ripped open while the yellowish pulp and seeds are removed from the pods. The empty pods are the needed raw material. The pods make up $39 \%$ of the weight of the fruits while the mealy yellowish pulp and seeds make up 61\% (Adama \& Jimoh, 2011).

Low cost mass housing delivery to low income earners in Nigeria have remained a huge challenge. Recently the Federal Government launched a Mortgage Refinance scheme to produce ten thousand houses for the people. One of the factors militating against affordable housing is the high cost of cement. A way out is replacing a proportion of cement with cheap and available pozzolanic materials. Pozzolana defined as a "and aluminous material which in themselves have little or no cementitous properties but in siliceous finely divided form and in the presence of moisture they can react with calcium hydroxide which is liberated during the hydration of portland cement at ordinary temperatures to form compounds possessing cementitous properties" (Adama \& Jimoh, 2011).. Pozzolana have the characteristics of combining with the free lime liberated during the hydration process of Ordinary Portland Cement (OPC) to produce stable, insoluble calcium silicates thus reducing the process of mortar and concrete attacks from sulphate, salts and chlorides. By-products mineral admixtures such as fly ash, rice husk ash and ground granulated blast furnace slag contribute to improvement of concrete performance (for example, high strength, high durability and reduction of heat of hydration) as well as reduction of energy and carbon dioxide generated in the production of cement. 
The African Locust bean tree (Family Legumianosae: Mimosodeae) with scientific name Parkiabiglobosa is a deciduous tree that grows up to $20 \mathrm{~m}$ in height (Hausa: Dorowa). The tree grows in much of sub-sahara Africa and commonly found in Nigeria. It grows large fruit pods that contain both sweet yellow pulp and valuable black seeds. The seeds are used for food seasoning when fermented (Hausa: Dadawa, Igbo: Ogiri Yoruba: Iru). Various parts of the tree are also used for medicinal purposes. The brown Pod is usually peeled off to free the fruit and seeds and left as waste material. As an agricultural waste material it constitutes environmental nuisance hence its use as a building material has economic advantage. An investigation in the use of the pod extract as a binder showed that the extract improved the compressive strength of laterite blocks by 78.5\% - (Aguwa \& Okafor, 2012).

\subsection{MATERIAL AND METHOD}

\subsection{Locust Bean Waste Ash}

The ash used was obtained locally from the burning of locust bean husks sourced from Tsauni village in Zaria L.G, Kaduna State and Shafan Koto village in Toto L.G, Nassarawa state. The husks were completely burnt under atmospheric condition, sealed in plastic bags and transported to the laboratory. The ash was then passed through British Standard No 200 sieve, with $0.75 \mathrm{~mm}$ aperture, and kept to be mixed with the cement in the pre-determined percentages.

\subsection{Materials}

The locust bean waste used in this research were sourced from Tsauni Village in Zaria L.G, Kaduna state and Shafan Koto village in Toto L.G, Nassarawa state of Nigeria. The material is usually available as a waste product of agricultural processing of the locust bean fruits during the harvest season. LBPA was produced by incineration attaining $500^{\circ} \mathrm{C}$, after which the ash was sieved using sieve 200microns, Ordinary Portland cement (Dangote 3X), sand and gravel

\subsection{Compressive strength test}

Compressive strength of concrete cube test provides an idea about all the characteristics of concrete. By this single test one judge that whether Concreting has been done properly or not.

Compressive strength of concrete depends on many factors such as water-cement ratio, cement strength, quality of concrete material, quality control during production of concrete etc.

For cube test, casting was done using $150 \mathrm{~mm}$ X $150 \mathrm{~mm} \mathrm{X} 150 \mathrm{~mm}$ concrete mould. The concrete is poured in the mould and tempered 35 times in three (3) layers properly so as not to have any voids. After 24 hours these moulds are removed and test specimens are put in water for curing. The top surface of these specimen is made even and smooth. These specimens are tested by compression testing machine (digital display) after 7 days 14 days 21 days and 28 days curing. Load are applied gradually until the Specimens fails. Load at the failure divided by area of specimen gives the compressive strength of concrete.

\subsection{RESULTS AND DISCUSSION}

Table 1 : Compressive Strength of Control, 5\%, 10\% and 15\% (Grade 20)

\begin{tabular}{|c|c|c|c|c|}
\hline \multirow{2}{*}{ Age (Days) } & \multicolumn{4}{|c|}{ Crushing strength (N/mm ${ }^{\mathbf{2}}$ ) } \\
\cline { 2 - 5 } & Control & $\mathbf{5 \%}$ Repl. & $\mathbf{1 0 \%}$ Repl. & 15\% Repl. \\
\hline 7 & 14.00 & 11.67 & 10.24 & 9.00 \\
\hline 14 & 21.00 & 19.67 & 16.67 & 11.13 \\
\hline 21 & 21.33 & 22.33 & 21.00 & 12.00 \\
\hline 28 & 28.33 & 23.00 & 22.33 & 13.43 \\
\hline
\end{tabular}


International Journal of Advances in Scientific Research and Engineering (ijasre), Vol 5 (4), April-2019

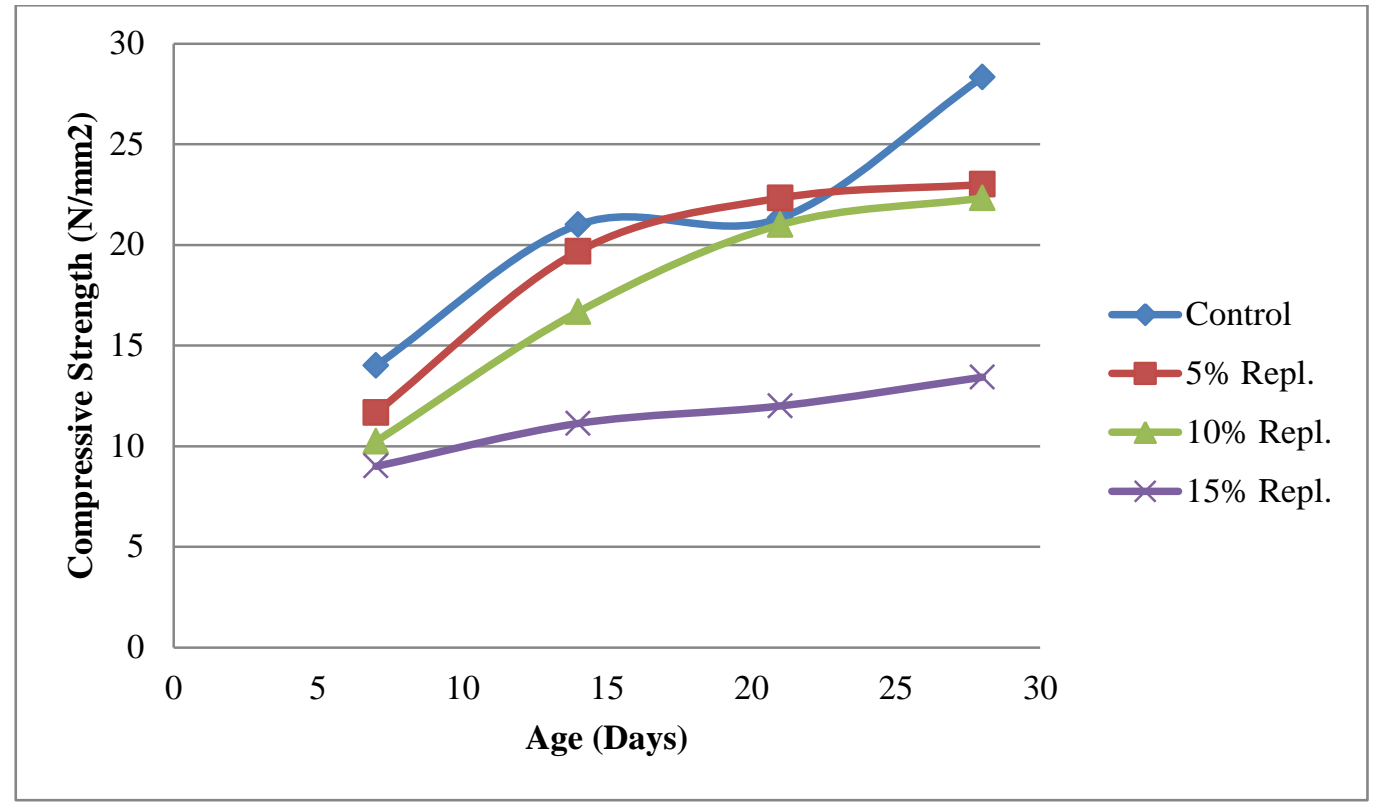

Fig. 1: A graph of compressive strength $\left(\mathrm{N} / \mathrm{mm}^{2}\right)$ against Age (Days) for Grade 20

Table 2 : Compressive Strength of Control, 5\%, 10\% and 15\% (Grade 25)

\begin{tabular}{|c|c|c|c|c|}
\hline \multirow{2}{*}{ Age (Days) } & \multicolumn{4}{|c|}{ Crushing strength (N/mm ${ }^{2}$} \\
\cline { 2 - 5 } & Control & $\mathbf{5 \%}$ Repl. & $\mathbf{1 0 \%}$ Repl. & $\mathbf{1 5 \%}$ Repl. \\
\hline $\mathbf{7}$ & 18.67 & 16.84 & 10.58 & 9.58 \\
\hline $\mathbf{1 4}$ & 22.10 & 19.98 & 11.59 & 11.59 \\
\hline $\mathbf{2 1}$ & 28.74 & 23.68 & 21.97 & 12.64 \\
\hline $\mathbf{2 8}$ & 30.40 & 25.27 & 24.38 & 13.38 \\
\hline
\end{tabular}

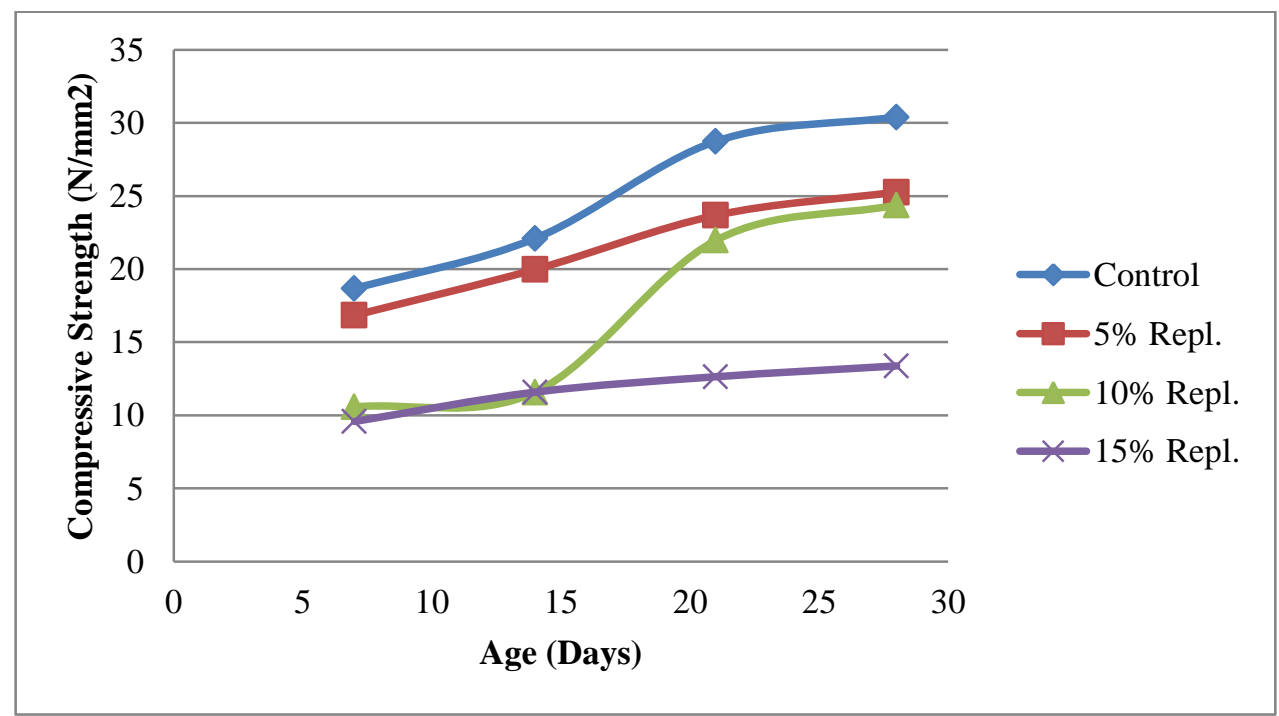

Fig. 2: A graph of compressive strength $\left(\mathrm{N} / \mathrm{mm}^{2}\right)$ against Age (Days) for Grade 25 
International Journal of Advances in Scientific Research and Engineering (ijasre), Vol 5 (4), April-2019

Table 3: Compressive Strength of Control, 5\%, $10 \%$ and $15 \%$ (Grade 30)

\begin{tabular}{|c|c|c|c|c|}
\hline \multirow{2}{*}{ Age (Days) } & \multicolumn{4}{|c|}{ Crushing strength (N/mm $\mathbf{2}^{\mathbf{}}$} \\
\cline { 2 - 5 } & Control & $\mathbf{5 \%}$ Repl. & $\mathbf{1 0 \%}$ Repl. & $\mathbf{1 5 \% \text { Repl. }}$ \\
\hline $\mathbf{7}$ & 22.55 & 18.01 & 11.52 & 10.00 \\
\hline $\mathbf{1 4}$ & 28.95 & 20.10 & 12.90 & 12.90 \\
\hline $\mathbf{2 1}$ & 36.47 & 24.01 & 23.57 & 13.57 \\
\hline $\mathbf{2 8}$ & 39.50 & 28.74 & 24.22 & 14.22 \\
\hline
\end{tabular}

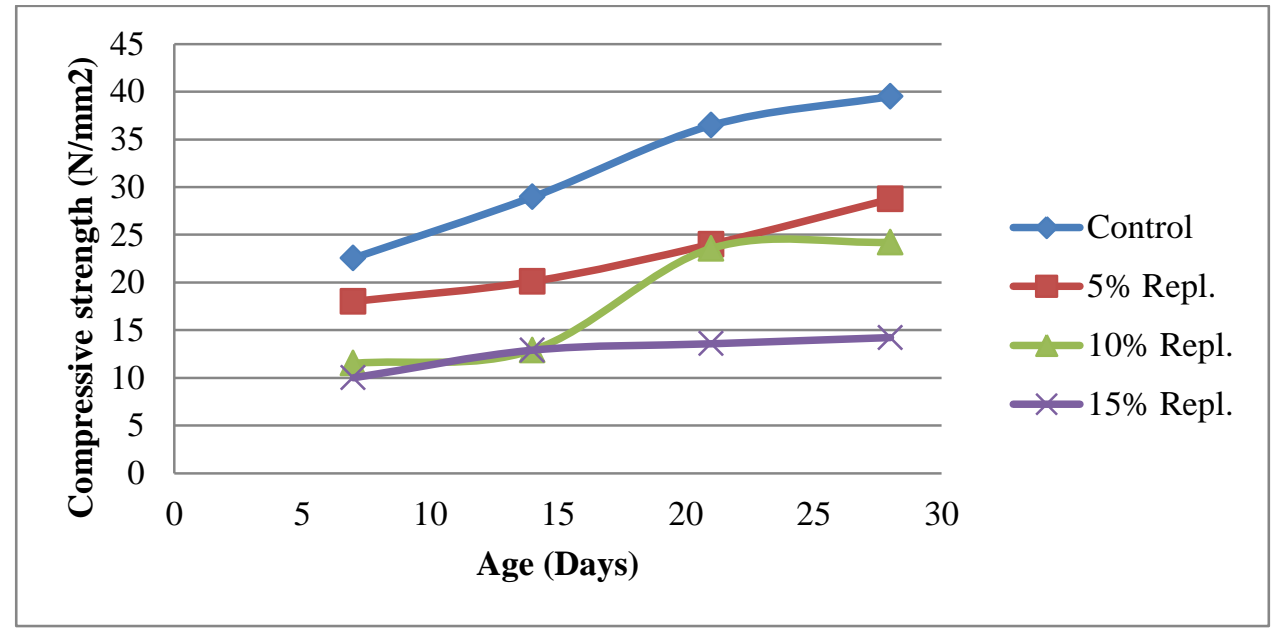

Fig. 3: A graph of compressive strength (N/mm²) against Age (Days) for Grade 30

\subsection{Discussion of Result}

The result obtained from the entire test carried out on the sample of concrete is as follows:

The result of Compressive Strength for Control, 5\% and $10 \%$ replacement in Grade 20, 25 and 30 are as follows: For Grade 20 at 7, 14, 21 and 28 days are, Control mix: 14.00, 21.00, 21.33 and $28.33 \mathrm{~N} / \mathrm{mm}^{2}, 5 \%$ replacement: 11.67, 19.67, 22.33 and 23 $\mathrm{N} / \mathrm{mm}^{2}, 10 \%$ replacement: $12.83,21.67,22$ and $23.33 \mathrm{~N} / \mathrm{mm}^{2}, 15 \%$ replacement: $9.00,11.13,12.00$ and $13.43 \mathrm{~N} / \mathrm{mm}^{2}$. For Grade 25 at 7, 14, 21 and 28 days are, Control mix: 18.87, 22.85, 28.85 and $30.53 \mathrm{~N} / \mathrm{mm}^{2}$, 5\% replacement: 16.67, 19.71, 22.98 and $25.11 \mathrm{~N} / \mathrm{mm}^{2}, 10 \%$ replacement: $10.95,12.03,16.27$ and $19.73 \mathrm{~N} / \mathrm{mm}^{2}, 15 \%$ replacement: $9.58,11.59,12.64 \mathrm{and} 13.38 \mathrm{~N} / \mathrm{mm}^{2}$. For Grade 30 at 7, 14, 21 and 28 days are, Control mix: 22.55, 28.95, 36.50 and 39.29 N/mm 2 , 5\% replacement: 16.34, 18.43, 24.01 and $2.74 \mathrm{~N} / \mathrm{mm}^{2}, 10 \%$ replacement: $10.52,10.90,11.57$ and $12.22 \mathrm{~N} / \mathrm{mm}^{2}, 15 \%$ replacement: $10.00,12.90,13.57$ and 14.22 $\mathrm{N} / \mathrm{mm}^{2}$ respectively.

The results of this trend may be due to a drop in workability with increase LBWA. Test to assess the workability of fresh concrete indicates that incorporation of LBWA in concrete leads to a decrease in slump value, which depends on the LBWA content. This reduction in slump was due to the absorption of some quantity of mixing water by LBWA particles.

Because of the large surface area of LBWA, more water molecules were attracted towards the surface of these particles. Thus, the quantity of the free water available for the concrete mix which helps in improving the fluidity of the mixture was decreased and there was an increase in the viscosity of the concrete mix. This in turn reduces the workability of the concrete and the effect was the same for other two tests also. If density were to be considered according to BS877, the concrete using LBWA would have been considered a light-weight concrete.

\subsection{CONCLUSION}


From the result obtained in this study, it can be concluded that locust beans waste ash can be used as a potential material for replacing cement. There is an increase in strength with increase in curing age, a decrease in strength with an increase in percentage replacement of the locust bean waste ash.

\subsection{Recommendations}

Although, the results of this study have shown a significant reduction in compressive strength of concrete utilizing LBWA than normal concrete, it could be recommended that LBWA concrete should be used in road curbs, concrete blocks, non-bearing concrete walls, precast units (partition walls, concrete blocks for Architectural applications and some cases of slabs on soil, culverts, sidewalks, drive ways), foundation pads for machinery, etc. It is here by recommended that further study should be carried out under proper supervision on the LBWA in concrete by the addition of admixtures such as silica fume and sodium hydroxide at different percentage in other to overcome the significant reduction of concrete strength due to replacement with LBWA

\section{ACKNOWLEDGEMENT}

This research is sponsored by Tertiary Education Trust Fund (TETFUND)

\section{REFERENCES}

1. Adama, Y. and Jimoh, Y.A. (2011). Production of and classification of Locust Bean Pod Ash as a Pozzolana: Project Report. Engineering Civil Engineering Portal. Available: <http://www.engineeringcivil.com/production-andclassification-of-locust-bean-pod-ash-lbpa-as-a-pozzolan.html >.

2. Aguwa, J.I and Okafor, J.O. (2012). Preliminary Investigation into the use of Locust Bean Pod Extract as Binder for production of Laterite Blocks for Buildings. International Journal of Environmental Science and Engineering Management Research. Vol.1, No. 2, Pp. 1289-1297

3. Akinmade (2008). The Effects of Locust Bean Waste Ash on the Geotechnical Properties of Black Cotton Soil. Unpublished M.Sc. Thesis, Department of Civil Engineering, Ahmadu Bello University, Zaria.

4. Akintayo, E.I. (2004). Characterization and Composition of ParkiaBiglobosa and Jathrocucas oils and cakes. Bioresources Technology. 92:307-310

5. Akoma, O. Onuoha, S.A. Akoma, A.O. and Ozigis, A.A. (2001). Physical-Chemical attributes of Yellow Pulp of ParkiaBiglobosa using Traditional Juice Extraction Technique. Nigerian Food Journal. 19:76-79

6. Basha, E.A.; Hashim, R.; and Muntohar, A.S. (2003). Effect of the cement - rice husk ash on the plasticity and compaction of soil. The Electronic Journal of Geotechnical Engineering 8: Bundle A. Available: <http://www.ejge.com/2003/Ppr0304/Ppr0304.zip>.

7. Campbell-plat, G. (1980). African Locust Bean and its African fermented product-Dawadawa. Economics of Food Nutrition. 9:123-132

8. Czernin, W. (1962) Cement Chemistry and Physics for Civil Engineers, Crosby Lockwood; London.

9. Hagos, T.H. (1962). A Revision of Genius ParkiaBiglobosaIn Africa, ACTA Botanica, Netherlandica. 11: 231-265

10. Irvine, F.R. (1961). Woody Plants of Ghana with Special References to their Trees. Oxford University Press, London. Pp. 868

11. National Cleaner Production Center. (2010). Report II Waste Biomass Quantification and Characterization. Sri Lanka

12. Neville, A.M. (1996). Concrete Technology. Longman, London

13. Page, C.L and Page, M.M. (2007). Durability of Concrete and Cement Composites. C.R.C Press, Boca Raton. New YorkWashigton D.C

14. Ransom, W.H. (1987). Building Failures, Diagnosis and Avoidance. Taylor and Francis Group, London

15. Shetty, M.S. (1982). Concrete Technology Theory and Practice. S. Chand and company LTD. Ram Nager, New Delhi

16. Smith, R.G. (1992). Alternatives to Ordinary Portland cement. British Building Society, Journal, vol. 25, Pp. 1-17

17. Wesche, K. (1997). Fly Ash in Concrete, Properties and Performance. An In-print of Chapman and Hall, London 